\title{
Making Sense of the 'Coloured' Vote in Post-Apartheid South Africa: Comparing the 1994 and 1999 Provincial Results in the Western Cape
}

\begin{abstract}
By
Sean Jacobs

The author is a doctoral student at the University of London, Birkbeck College. He also works as a senior researcher at the Institute for Democracy of South Africa in Cape Town, South Africa. E-mail: sean@idasact.org.za. I would like to thank Jessica Piombo, Lia Nijzink, Brent Simons, Jonathan Faull and Leonard Martin in Denmark for reading and commenting on different drafts. To Elaine Salo-Miller and Irvin Kinnes for their comments during the earlier parts of the research of this paper.
\end{abstract}

\section{Introduction}

The voting behaviour of coloureds ${ }^{1}$ in South Africa's short history of democratic elections has often been treated in an off-hand or simplistic manner. Those most guilty of this abuse have been the popular mass media and political party activists. As a result, existing interpretations of coloured voting patterns in the national and provincial elections of 1994 and 1999 invent 'traditional' voting patterns for coloureds or even reify a homogenous coloured voting bloc. Media commentators and political party activists have often dealt with coloured voters as if they are a single, homogenous entity, with little regard for factors of class, region, religion or the impact of self-identification. ${ }^{2}$ For example, when the majority of coloured voters opted for the National Party (NP) in the first democratic election in 1994, interpretations of that vote - rather than interrogating it - sought to conveniently explain it through supposed 'traditional voting patterns' or coloureds' supposed 'historical affinity' for the NP.

The above interpretation does not faze these experts and commentators. In contrast, historical evidence points to more complex political and voting behaviour. For one commentator, organised coloured political activity had historically been centred on some form of opposition to the NP. ${ }^{3}$ However, that opposition displayed the contradictions and limitations of politics under apartheid. For example, those coloureds who did qualify to vote under colonialism voted for the white opposition parties. The same voting pattern was recorded for the elections of the Tricameral Parliament after 1983 where voters opted for 'coloured' political parties explicitly opposed to the apartheid policy. However, by participation in these elections, the coloured political parties provided the 'separate, but unequal' electoral system with 
legitimacy. And while it is conceded that the party associated most with this kind of politics, the Labour Party, was later absorbed into the NP, its early and dominant interpretation of its history was that of an obstructionist collaboration with apartheid. ${ }^{4}$

In the 1980s left wing and popular opposition to the apartheid government was particularly strong in coloured townships in the Western Cape. The United Democratic Front (UDF), effectively the internal wing of the banned African National Congress (ANC), was based in the Western Cape, and was launched in the coloured township of Mitchell's Plain on 20 August 1983. Many of its leading activists came from organisations that were particularly strong in coloured areas. These included Cheryl Carolus (from Bonteheuwel and now South African high commisioner to the United Kingdom), Trevor Manuel (from the Cape Areas Housing Action Committee and now Minister of Finance in the South African government) and Dr Allan Boesak (cleric and one-time UDF patron). ${ }^{5}$

Conclusions about 'traditional voting patterns' are historically inaccurate given the low levels of coloured polls in apartheid separate elections and their highly restrictive nature. Under colonial law coloured and African men in the Cape Province (the present Western and Eastern Cape) had the franchise. This was, however, highly prescribed since, apart from gender, access to property and education were linked to voting rights. The potential poll among coloureds was therefore very low anyway. In 1951 the NP government introduced the Separate Representation of Voters' Bill which sought to disenfranchise coloured men in the Cape. By then African men had already been disenfranchised.

If the colonial vote was highly exclusive, then the exclusively coloured elections of the Tricameral Parliament in 1984 and 1989 could barely average a poll of 15\% given its legitimacy problems at the height of popular resistance to apartheid, particularly in the Western Cape, where the bulk of people classified 'coloured' under apartheid, live. ${ }^{6}$ 'Traditional voting patterns' also implies that the voters have familiarity with the voting process. However, surveys done before the 1994 elections confirmed that levels knowledge of electoral processes among the coloured population were particularly low. ${ }^{7}$

\section{Comparing Coloured Voting Behaviour in 1994 and 1999}

If assumptions about coloured voting patterns have historically been erroneous, then trying to understand and predict 'coloured' voting patterns is fraught with pitfalls for any researcher. The 1994 election pointed to some of the major problems. In that election, it was difficult to conclusively make predictions on coloured voting patterns since the total number of voters classified as coloured was not known. The fact that no voting figures were collected by race was a major factor in this regard. ${ }^{8}$ Registration was not linked to specific geographical

In 1983 as part of the reform of apartheid, the government introduced a 'Tricameral Parliament' consisting of three separate 'houses' for whites, coloureds and Indians. However, the whites held effective political power having jurisdiction over matters that affected all races, while the coloured and Indian houses only had some jurisdiction over certain 'own affairs' which included education, health and welfare services. Blacks (Africans) were excluded from these reforms.

5 See Tom Lodge, 'Rebellion: The Turning of the Tide' in All Here and Now: Black Politics in South Africa in the 1980s, edited by Tom Lodge and Bill Nasson, New York, Ford Foundation, 1991 Robert Mattes, Hermann Giliomee and Wilmot James, 'The Election in the Western Cape', in Launching Democracy in South Africa. The First Open Election, April 1994. RW Johnson and Lawrence Schlemmer (eds), Yale University Press, 1996, p117

8 In their volume, Now That We Are Free: Coloured Communities in a Democratic South Africa, Cape Town, Idasa/Friedrich-Naumann Stifting, 1996, editors Wilmot James, Daria Caliguire and Kerry Cullinan includes a number of tables detailing the 1994 election result among coloureds. These were, however, rough estimates and in no way reflected the actual election. 
locations. As a result, voters could cast their ballot at any polling station. Given that apartheid residential patterns largely remain intact, geographical registration could have assisted researchers in better analysing and detecting voting trends.

Problems at under-resourced polling stations in African 'townships' resulted in many voters from those areas being bussed to polling stations in neighbouring coloured townships that were recording lower levels of voter activity or often, were deserted. While this assisted election administrators in ensuring a 'free and fair' poll and that the majority of voters cast their ballots, it presents problems for researchers analysing voting patterns.

A related problem for researchers is, unlike in 1999, when the research industry around elections was much better resourced and established, in the run-up to the 1994 election, opinion polling in South Africa was still a novelty and was highly mistrusted or ridiculed by participants in the elections, particularly by political parties and previously disenfranchised voters. The 1994 election, though, served as a trial run for opinion polling in South Africa, and by the time of the second democratic election in June 1999, a much more systematic practice of election analyses - which included comprehensive opinion poll series, interviews and interpretative analyses as well as a number of qualitative reports - resulted in a more accurate picture of voting preferences.

This paper will restrict its analysis of coloured voting behaviour to the Western Cape province. The Western Cape is the one province that indicates coloured voting preferences most clearly. An estimated $61 \%$ of the coloured vote is concentrated in the province. The Western Cape and the Northern Cape are unusual among South Africa's nine provinces in that African voters represent a minority of the electorate in these provinces. In the Western Cape whites constitute a quarter of the voting age population and Africans one-fifth. ${ }^{9}$ The result in the province is therefore crucial in indicating coloured voting preferences, and thus will serve as the case study for this analysis.

\section{The Result in 1994}

\begin{tabular}{lrr}
\multicolumn{3}{c}{$\begin{array}{c}\text { Provincial Election Results Western Cape Province, } \\
1994 \text { and } 1999^{10}\end{array}$} \\
Parties & $\mathbf{1 9 9 9}$ & 1994 \\
ANC & $42.07 \%$ & $33.0 \%$ \\
NNP & $38.39 \%$ & $53.3 \%$ \\
DP & $11.91 \%$ & $6.6 \%$ \\
ACDP & $2.79 \%$ & $1.2 \%$ \\
UDM & $2.40 \%$ & - \\
PAC & $0.49 \%$ & - \\
Total & $100.00 \%$ & $100.0 \%$
\end{tabular}

Source: Government Gazette, No 20201, 11 June 1999, Electoral Commission, 'Results, Allocation of Seats and Basis for Determination of Seats in Respect of the Election Held on 2 June 1999', p20; Election 94, South Africa. An Analysis of the Campaigns, Results and Future Prospects, Andrew Reynolds (ed.), Cape Town: David Philip, pp202-203.

Andrew Reynolds (ed), 'The Results', Election '99 South Africa. From Mandela to Mbeki, p190 Government Gazette, No 20201, 11 June 1999, Electoral Commission, 'Results, Allocation of Seats and Basis for Determination of Seats in Respect of the Election Held on 2 June 1999', p20; Election 94, South Africa. An analysis of the Campaigns, Results and Future Prospects, Andrew Reynolds (ed), Cape Town, David Philip, pp202-203 
The NP scored a decisive victory in the 1994 provincial election in the Western Cape (see table above). This result was largely duplicated in the national elections, which were held on the same day. The implication of the result was that the NP had emerged as the victor in the contest for the support of the coloured voters. Some estimates at the time suggested that the NP victory was because the party won about three times as many votes from among coloureds as had the ANC. ${ }^{11}$

The NP's strong showing came as a surprise, and did not make rational political sense to most observers, given its role in the official state oppression of coloured people. It is probably this result which led to comments about 'traditional affinity' of coloureds to the NP. As a result the immediate post-election period was characterised by much hand wringing and soul searching on the part of media, party activists and social scientists over the voting behaviour of coloureds. ${ }^{12}$

Instead of offering new perspectives much of the writing and public debates focused on the old debate around the category 'coloured' and the ways in which it is socially constructed (including by coloured people themselves). A second line of inquiry concerned the empirical question of whether coloured voters actually do vote differently from other voters: that is whether being coloured affects how or why people vote and especially how much it relates to other factors. ${ }^{13}$ While most of these critiques that emerged after the 1994 elections are useful for the study of identity and identity politics, they could not tell us anything about the anticipated political behaviour of 'coloured voters', neither did they provide any insight into the tactics of political parties who were contesting the vote. It is therefore not surprising that South Africa's second democratic elections on 2 June 1999 was not spared the question of 'Who will coloured people vote for this time around?' In an otherwise flat campaign, the 'coloured voting question' again gained prominence, unsurprisingly, in the Western Cape. ${ }^{14}$

The key questions for this paper are: Did any fundamental changes take place in voting preferences among coloureds between South Africa's first and second democratic elections? What happened to the NNP's coloured support? What does the provincial result mean for long-term predictions of coloured voting preferences? And, what specifically does it mean for the ANC — strategically and organisationally — in relation to the 'coloured vote'?

When the 1999 elections were over the press re-opened the coloured voting question in their post-elections analysis. With few exceptions they could not tell us anything new. In fact, most media analysts were surprised at the outcome and had not anticipated such a big swing away from the NNP, despite the fact that opinion polls had been indicating it for months. A number of articles soon appeared, ranging from a very optimistic interpretation suggesting major swings in coloureds' voting preferences on the one hand, to an overly cautious approach suggesting limited or no change at all on the other. ${ }^{15}$

This essay will contend that both approaches contain some element of what had transpired in the elections. Indeed there was some swing in coloured voting — particularly among coloured rural and middle class voters — but at the same time the NNP managed to retain its

11 James, Caliguire and Cullinan, 1996, p39

12 The highlight was the Institute for Democracy in South Africa (Idasa) conference on coloured identity which resulted in the volume Now That We Are Free: Coloured Communities in a Democratic South Africa, 1996, which contained contributions from ANC and NP politicians, community activists and academics.

13 James, Caliguire and Cullinan, 1996, p29

14 It was clear throughout that the ANC was assured of a clear majority of the national vote. The real contest was over a distant second place between two white-orientated parties as well as the two provinces of Kwazulu-Natal and the Western Cape. Mail and Guardian, 11 June 1999 
strong support among urban, working class voters who had served as the basis for the NP victory in 1994. What affected the 1999 result considerably, however, were the legal criteria of registration and the factor of turnout at the polls. The essay also argues that the 1999 election provides the ANC with some hope of gaining a post-apartheid coloured vote. The essay furthermore contends that in the 1999 election the ANC broke through a 'psychological barrier' in terms of its efforts to win the coloured vote from the NNP. Finally, the essay holds that a different organisational approach by the ANC (and one noted long noted by a number of Western Cape-based ANC 'coloured' activists) that addresses the specific material and political concerns of urban coloured working class voters may reap electoral dividends for the ANC or any other party taking this route.

\section{Changes in Voting Preferences Among Coloureds}

The most significant message of the 1999 provincial election result in the Western Cape is that the NNP did not hold as much sway over coloured voters as was assumed. In fact, the apparent entrenchment of the NNP in the coloured community was not as self-explanatory as it seemed. According to the 1999 election result the major shift in coloured voting preferences had taken place in the rural areas of the Western Cape, ${ }^{16}$ where the ANC had won the support of the majority of farm workers as well as coloured townspeople. ${ }^{17}$

In the 1994 provincial election the result had been so predictable that it was already clear who had won halfway through the count. The 2 June 1999 provincial election outcome was much more difficult to predict in the Western Cape. When the results came out, the NNP did not have a clear majority. It was obvious that the party's 1994 base was under attack. The NNP's control of the white vote was significantly challenged by the Democratic Party, but more importantly, its coloured support in the province — with the exception of working class metropolitan areas — was clearly not united behind the party programme and leadership.

A series of political factors conspired to affect the NNP's voting support among coloureds. Firstly, the NNP had experienced a decline in both its national and provincial support between the 1994 election and the period leading up to the 1999 election. Support was halved between 1994 and 1999. An Idasa survey showed that nationally, voting intention among NNP supporters declined from 16\% among all potential voters in September/October 1994 to $7 \%$ in April $1999 .{ }^{18}$ Party identification among all potential voters declined from $15 \%$ in September/October 1994 to 3\% in April 1999. Among coloured voters, the largest voting bloc in the province, party identification for the NNP declined from $28 \%$ to $13 \%$ over the same period. $^{19}$

Second, leadership changes had a significant impact on the NNP's voter support. The departure of FW de Klerk, as well as party secretary Roelf Meyer (favoured to succeed De Klerk and who wanted the NNP to change from a largely white organisation to a more representative party), was probably felt the most. For coloured voters in the Western Cape, De Klerk, who was the NNP leader since 1989 and the country's state president throughout the negotiations

The main areas of the rural Western Cape are the Boland, the Southern Cape and the Karoo. The Boland and surrounding areas include the Breede River area, the winelands, the Overberg and the West Coast. The Breede River area consists of rural farmlands and agricultural towns of which Paarl and Worcester are the largest. The main towns in the Southern Cape are George, Mossel Bay, Oudtshoorn and Beaufort-West. The region includes the Little Karoo and Central Karoo.

See Elections Results at Independent Electoral Commission (IEC) website: http://www.elections.org.za

'Party support and voting intention', Opinion '99, Released by Idasa Public Opinion Service, No 2/4 24 May 1999, p2

Ibid, p9 
period (1990-1994), was the embodiment of the changed NNP. De Klerk's successor, Marthinus van Schalkwyk, was none of these. Van Schalkwyk was derided in the press as being too junior (kortbroek or 'short pants'), while for core supporters he could not provide a clear vision of the NNP in a post-apartheid context. ${ }^{20}$ Meyer's resignation and founding of the United Democratic Movement (UDM) along with former ANC member, Bantu Holomisa, certainly affected the NNP support base. While the Meyer resignation and defection had less impact on the support base, it did make some gaps in the party's support base (especially among Afrikaners and rural coloured people). ${ }^{21}$

Thirdly, beyond political factors the institutional factor of registration considerably affected the electoral performance of political parties. In the 1999 national and provincial elections, unlike those in 1994 where all adult South African citizens could vote, the qualification for voters was qualitatively different. Firstly, only South African citizens with barcoded identity documents and who had registered could vote. Furthermore voters could only vote within the locality where they had registered. ${ }^{22}$ From the start of the campaign it was clear that coloured NNP supporters were less keen than were ANC supporters in participating in the elections and that registration would have an impact on the result. In fact, registration among the NNP's core constituency of coloured working class voters was quite low throughout the initial stages of registration and only picked up after a concerted attempt by party workers and activists to get their supporters out to register. Survey research by Idasa indicated that the two main reasons for not registering were that 'there is no reason to vote' and 'there is no difference between the parties'. ${ }^{23}$

Compounding the dip in national support due to leadership changes, the party was suffering at the provincial level as well. Party identification with the Western Cape NNP dropped from $41 \%$ in 1994 to 13\%. This was partly a consequence of the NNP provincial government in the Western Cape receiving only lukewarm reviews from voters, with especially low ratings given to Premier Gerald Morkel. In contrast to Morkel, respondents gave President Mandela and Deputy President Mbeki improved ratings. The national government also received more positive feedback from prospective voters. Western Cape voters also appeared the most pessimistic about economic prospects. ${ }^{24}$

Furthermore, it appeared that the NNP in the Western Cape was under assault from the ANC's provincial organisation, which engineered a number of high profile defections of NNP politicians in a careful strategy to make inroads among potential coloured voters. The defections resulted especially in key coloured leaders leaving the party. A number of smaller parties, most notably the DP, also benefited from the defections. There is, however, some proof that the defections did not have much short-term effect. A newspaper opinion poll conducted in two Cape Town coloured townships where local NNP politicians had defected to the ANC, showed that the defections had no effect on NNP support base there. Be that as it may, the NNP had reason to fear the loss of its position of power in the Western Cape. ${ }^{25}$ 


\section{The Rural Vote}

\begin{tabular}{lr}
\multicolumn{2}{c}{ Table 2: Ceres Transitional Local Council (TLC) Provincial } \\
Result
\end{tabular}

\begin{tabular}{lr}
\multicolumn{2}{c}{ Table 3: Bella Vista High School Polling Station } \\
Parties & 1999 Result \\
ACDP & $0.81 \%$ \\
ANC & 56.05 \\
DP & 2.15 \\
NNP & 37.04 \\
PAC & 3.41 \\
UDM & 0.09 \\
Other & 0.45 \\
Total & $100 \%$ (1 1 1 voters $)$
\end{tabular}

Source: Independent Electoral Commission, http://www.elections.org.za

\begin{tabular}{lr}
\multicolumn{2}{c}{ Table 4: Community Centre Bella Vista Result } \\
\hline Parties & 1999 Result \\
\hline ACDP & $1.22 \%$ \\
ANC & 54.56 \\
DP & 1.82 \\
NNP & 39.97 \\
UDM & 0.67 \\
Other & 0.76 \\
Total & $100 \%$ (658 voters)
\end{tabular}

Source: Independent Electoral Commission, http://www.elections.org.za

Voters in rural towns comprise at least a third of the voting age population in the Western Cape. In most of these towns, the majority of voters, sometimes as many as $80 \%$, could be described as coloured. Economic migration patterns of the last ten years have resulted in an increased African population in these rural towns, but their numbers are too small to make any significant impact on the voting result. Most Africans still live either in the Cape Metropolitan area or on the fringes of the metropolitan area. As a result, the ANC would have to win significant coloured support to receive more than half of the votes in most rural towns. 
The 1999 provincial election result (Table 1) indicates an ANC swing vote among coloured voters. Tables 2, 3 and 4 indicate the results in Ceres - a town in the Koue Bokkeveld — that represents the typical voting distribution in most Boland towns. This result was replicated elsewhere. In the southern Cape and Karoo of the Boland the ANC won more coloured votes that the NNP. In the southern Cape, it dominated key towns such as George, Mossel Bay and Knysna. ${ }^{26}$

The results for the west coast region of the Boland, which includes a number of larger towns such as Saldanha and Vredendal, also indicated an improved showing for the ANC. However, the election result for the much more urbanised areas on the west coast peninsula pointed to a closer contest for coloured voters between the ANC and NNP. For example, in the West Coast Peninsula Transitional Local Council (TLC) ${ }^{27}$ the ANC's lead was much lower at $49.61 \%$ of 19294 votes. The NNP was a close second with $38.61 \%$ of the vote. But at some polling stations in the west coast peninsula, the ANC surged further ahead of the NNP. ${ }^{28}$ However, results at polling stations for the rural Western Cape did not always favour the ANC. For example, Beaufort West, one of the bigger towns in the Karoo, went to the NNP. Even coloured voters in the surrounding farms falling under the Beaufort West transitional rural council persisted in their support for the NNP. At least $51.77 \%$ of the voters chose the NNP as opposed to $36.27 \%$ voting for the ANC and a fairly significant $6.56 \%$ for the DP. The NNP also won some towns on the west coast. In the Velddrif TLC that borders the West Coast Peninsula TLC, the NNP received $51.73 \%$ of the vote against the NNP's $35.69 \%$. But on balance the ANC won the majority of votes in the rural Western Cape.

What explained the nature of voter choice vote among rural coloured voters in the 1999 election? One reason advanced for this swing to the ANC was that it was not a sudden shift in voter attitudes, but rather a gradual increase. This change is traced back to the 1995 local government election when the ANC won the majority of contests in rural town councils in the province. Arguably then, the swing vote is not surprising and is rather a reflection of how the ANC consolidated its support. While there may be some truth to this view, it does not account for the fact that issues in local elections differ from those in provincial elections. In fact, in the lead-up to the 1999 election, the ANC had contested a number of by-elections in coloured areas and had lost either to the NNP or the UDM. For example, after the ANC lost a ward by-election in the town of Zoar to the UDM, and in another instance, the entire ANC branch defected to the Pan-Africanist Congress (PAC) in Calitzdorp in the Little Karoo. As a consequence, a number of newspaper and public commentators suggested the ANC would do badly among rural coloured voters. However, during the 1999 election the ANC swept the vote in both areas.

There are other reasons for the ANC's improved electoral fortunes. Firstly, it could count on improved organisational capacity and better and more focused leadership — both at the provincial level and within the rural sub-regions - during the 1999 election in contrast to the 1994 election. Secondly, improvements in material conditions associated with government reforms probably also impacted on the result. This was largely because of a rural focus by ANC ministers in the provincial cabinet who initiated a number of infrastructure projects as part of against the NNP's $32.51 \%$. IEC results also indicated that the ANC averaged $50 \%$ in former coloured group areas. IEC website.

27 The West Coast Peninsula Transitional Local Council consists of the towns of Saldanha Bay, Vredenburg and St Helena Bay.

28 At the Louwville Community Hall polling station in Vredenburg, for example, the ANC received $57.72 \%$ of the vote against the $34.79 \%$ of the NNP. Source: IEC Website. 
the Reconstruction and Development Programme (RDP). These included programmes on housing, basic services in health care and education, as well as public works schemes such as building of roads and public amenities. The three ANC ministers in the provincial cabinet served in the key ministries of Trade and Industry (Chris Nissen), Health (Ebrahim Rasool) and Transport (Leonard Ramatlakane). Nissen actively promoted a number of RDP forums among local, mainly coloured and African, rural communities. The RDP forums facilitated development projects in these towns. They have been less successful in urban areas.

The ANC's improved showing among farm workers in the 1999 election is especially significant, given the fact that voters on farms are often cut off from canvassing by party activists and frequently the subject of threats and intimidation by NP-supporting white farmers. How to explain this? A number of factors accounted for this improved showing, most notably the fact that the working and living conditions on white-owned farms had changed for the better for most farm workers since 1994. The national government had introduced a number of legislative measures - already passed or pending - on tenancy rights and minimum wages. The relations between farmers and workers are still tense and fraught with racism, with white farmers continuing to exploit black workers. In such a context, legislation by the ANC to improve conditions of farm labourers contributed to an affinity of coloured farm workers with the national (ANC) government.

What should be investigated is to what extent the support for the ANC among rural coloured voters was not based on positive criteria. Rural coloured people are not as directly affected by the affirmative action controversies which often feed animosity between working class coloured and African communities in the urban areas of the Cape and which considerably benefit the NNP and the DP.

\section{The Urban 'Coloured Vote'}

\begin{tabular}{lr}
\multicolumn{2}{c}{ Table 5: Central Cape Town Metropolitan Local Council } \\
Provincial Result
\end{tabular}

Source: Independent Electoral Commission, http://www.elections.org.za 


\begin{tabular}{lr}
\multicolumn{2}{c}{ Table 6: Tygerberg Metropolitan Local Council } \\
Parties & 1999 Result \\
ACDP & $2.56 \%$ \\
ANC & 45.91 \\
DP & 8.75 \\
NNP & 38.33 \\
UDM & 2.89 \\
Other & 1.56 \\
Total & $100 \%$ (340 330 voters)
\end{tabular}

Source: Independent Electoral Commission, http://www.elections.org.za

Of the 1.6 million registered voters who cast their ballots in the 1999 provincial election in the Western Cape, the vast majority - 64.4\% — are urbanised and live in the Cape Town metropole, an area that comprises six large municipal 'substructures'. Coloured voters form the bulk of the voters in this area. The metropole is therefore a crucial indicator of overall preference of coloured voters. In terms of transitional constitutional arrangements around local government, there is one metropolitan council in the Western Cape, the Cape Metropolitan Council. The second category of municipal local government is the substructure, or municipal local council (MLC), of which there are six: Cape Town Central, Blaauwberg, Helderberg, Tygerberg, Oostenberg and the Southern Peninsula. The substructures consist of a number of transitional local councils. The two most crucial are the Northern and Cape Town Central substructures, which have the most number of voters in the metropole and the highest number of coloured voters.

There are 1.04 million voters in the Cape metropole, of which 36\% are in the Central Cape Town MLC and 32.7\% in the Tygerberg MLC. Whichever party dominates these areas dominates the regional vote, and more importantly, the coloured vote. The results for these two substructures (Tables 5 and 6) indicate an improved showing for the ANC in Cape Town Central as against a declining support for the NNP, while in the Tygerberg substructure the ANC achieved a $6 \%$ lead over the NNP. While it could be argued that it was the fact that the bulk of African people in the Western Cape live in these two MLC areas which swung the vote to the ANC, coloureds still form significant majorities, even in these areas. However, in these MLCs the NNP maintained its hold on working class, coloured voters. It controlled the remaining four MLCs. In the Blaauwberg MLC only 27.69\% of the 48548 registered voters chose the ANC as opposed to NNP's 46.03\%, while in the Southern Peninsula Substructure with its 132 186 voters, the NNP won $43.19 \%$ of the vote against the ANC's $20.56 \%$.

What explained this improved performance of the ANC and the decline of the NNP among urban voters? I have argued earlier that the NNP suffered declining support in the run-up to the elections caused by its lack of clear leadership and strategy. This obviously considerably impacted on voter choice. Equally significant, though, was the impact of the 'fear' factor among coloured voters, notions of not being 'black enough' and economic factors. Unlike rural communities, urban working class coloured voters associated the ANC with the decline in the regional economy, particularly the textile industry, as well as with non-delivery.

Working class coloureds overwhelmingly see themselves as having a separate identity from 'Blackness', and also as being somehow better and more civilised than 'blacks' (meaning Africans). These perceptions have been very powerfully shaped by the apartheid era Group Areas Act and policies of preferential treatment for coloureds in terms of housing, employment and welfare services. 
The main issues identified by voters in the Western Cape and countrywide were jobs and housing. Housing proved a very emotive election issue, often exploited by opposition parties. Municipalities in the metropole had long practised racially exclusive housing policies that favoured working class coloured families. While this housing is of a sub-economic standard and overcrowding is rampant, NNP supporters saw the post-1994 influx of Africans to the urban Western Cape as rivals on already congested housing waiting lists.

This context of renewed competition over scarce resources such as housing and employment is the direct legacy of the scrapping of coloured labour preferences in the Western Cape and the outlawing of influx control policies, which had forcefully discouraged new, large-scale African (mainly Xhosa-speaking) migration from the neighbouring Eastern Cape province. Lately, immigration of a large Xhosa-speaking population has, however, vastly increased the size of squatter settlements next to coloured townships. This has fuelled swartgevaar fears ('fear of blacks') among coloureds. But even so, the NNP's introduction of swartgevaar tactics in its campaign failed to have a major impact on coloured support.

Thus far I have advanced two main explanations for the coloured vote; one, the impact of a series of institutional and political factors that conspired against the NNP to weaken the party's position among coloured voters; and two, the regional dimension of the vote. Regarding the latter explanation, it is clear that perceptions of delivery among coloured voters in rural areas had contributed to the ANC's improved showing. Western Cape agriculture had been less affected than farming in other provinces by the government's deregulation of the economy, and the wine and fruit industries had benefited from export expansion in the post-sanctions era. Hence, coloured farm workers were less likely to have been affected by redundancies than agricultural labour elsewhere, and labour laws reforms had improved conditions and promised better wages. The ANC could and did claim the credit for these improvements, pointing out that the NNP and the DP had opposed them in the National Assembly.

In urban areas, the ANC could not count on perceptions of delivery as these coloured voters associated non-delivery with the ANC. Here it adopted a different campaign strategy, relying on guidance from its provincial leadership and focusing on the particular needs of coloured voters. It was this approach by the ANC that played a crucial role in shifting support to it.

In addressing the concerns of urban coloured voters, the ANC's strategy, designed by the provincial chairperson, Ebrahim Rasool (former Health MEC), and entitled a 'Home for All', emphasised and ranked issues in the order of priority in which they were perceived by this constituency: crime, education, pensions, housing, land and unemployment. The party distributed 400000 copies of a pamphlet, Wat het die NP vir ons gedoen? ['What has the NP done for us?], in areas where the NP had strong support. These included Bellville, Elsies River, Bishop Lavis, Belhar and Delft. The ANC also strategically launched its 'Plan for the Western Cape' at the beginning of May in Delft, a bleak area of low-cost, municipal housing near the region's major airport. The plan called for an ANC majority to enable the reallocation of resources from rich districts to poor locations. Five pledges were spelt out; more police, quicker housing delivery, economic growth, job creation and stricter protection of the environment. The party also tapped into the cultural specificity of the region's music, when it commissioned a song, Dis Duidelik to appeal to its working class constituency. The song exploited the goema sound of the Cape with which most of the coloured working class voters could identify. The ANC had obviously learned from the NNP who had exploited the singing talents of NNP deputy leader, Peter Marais, in the 1994 national and provincial elections in its meetings in coloured areas. 
Rasool became identified with the campaign. On the advice of his electoral team, he gave it a localised feel. Although the ANC initially deployed its most senior leadership in the province to launch its campaign, it had a more deliberately localised focus than did ANC campaigns in any other province. President Mbeki presented the ANC's customary anniversary statement on 8 January 1999 in Athlone, Cape Town, accepted the civic freedom of the west coast town Vredendal, and attended an Eid service at a Claremont mosque.

Rasool's low-key, 'give us a chance' message was in sharp contrast to the aggressive confidence displayed by ANC activists in 1994. House-to-house visits and neighbourhood walkabouts replaced the triumphal mass rallies and toyi-toying of the 1994 election. And in small gatherings assembled in private houses in coloured townships, the ANC used leading politicians who had defected from the NNP, to explain its message to voters.

The ANC was more open and frank about its coloured identity in the Western Cape than in the 1994 election. Through its pamphlets and organisers, it suggested that the NNP was no party for bruin mense [coloured people]. The ANC argued that the NNP was still ruled by a white elite and its coloured leaders. These attacks were especially directed at Western Cape Premier, Gerald Morkel and Peter Marais, NNP member of the executive (MEC) for Health. The latter was portrayed by the ANC (through a very focused media campaign) as wanting to defect from the NNP and as he had accused the NNP leadership of being run by a white clique, was said, like Morkel, to be no more than a puppet or clown of the Broederbond. The campaign appears to have resulted in causing confusion among coloured NNP supporters about the sincerity of the NNP. When he eventually publicly stated his commitment to the NNP, the damage had already been done. The ANC argued that a Broederbond clique in the NNP was the explanation for the lack of transformation in the Western Cape. The pamphlets asked, 'Why is it that all the waiters at the Waterfront ${ }^{29}$ are white?' and 'Why did all the important civil servant jobs in the province go to whites?' The NNP did not know how to respond to the ANC's new found coloured identity, in contrast to the 1994 election when it impressed voters that the ANC's reluctance to deal differently with coloured voters from Africans was an affront to these voters. The ANC was careful, though, not to promote an exclusive coloured identity or coloured concerns at the expense of Africans in the province.

The ANC also dealt decisively with internal tensions between 'Africanists' and 'colouredists' in the organisation. This tension between African and coloured members had negatively affected the organisation's chances among coloureds in the 1994 election. In the run-up to the elections most of the Africanists were dealt with by either 're-deploying' ${ }^{30}$ them from the provincial to the national legislature, or by placing them in organisational positions where they could not exert influence over the politics of the province. Rasool's ascendancy as provincial leader over a period of two years prior to the election was also a sign of this shift.

\section{Conclusion}

Did any fundamental changes take place in voting preferences among coloureds between South Africa's first and second democratic elections? What happened to the NNP's coloured support? What does the provincial result mean for long-term predictions of voting preferences of coloured voters? And, what specifically does it mean for the ANC - strategically and organisationally in relation to the 'coloured vote'? 
This paper has shown with reference to selected results from the 1999 provincial elections and through qualitative inference that there were fundamental shifts in the voting preferences of coloureds from the 1994 to the 1999 election. The results showed that rural voters shifted to the ANC, while urban coloured working class either stayed away from the polls or small sectors shifted their vote to the ANC. However, that vote did not mean a positive identification with the ANC, but rather a reaction to the NNP's decline and lack of a clear strategy. The middle classes stayed solidly ANC, although there was some movement towards the DP, a trend that would be picked up in the 5 December 2000 local election. The NNP's coloured support was substantially eroded in the 1999 elections as a range of factors, both institutional and political conspired against it. It would be reasonable to ask if De Klerk had not retired from politics, whether the NNP would have done any better. While it is difficult to answer this question, one can speculate that the movement away from a politics of swartgevaar scare mongering to one of resources, has meant the end of the NNP, and despite the fact that it was later resurrected through its alliance with the revitalised Democratic Party, that resurrection was just that: it would not have been possible without the DP's involvement in NNP politics.

The 1999 election shows that the coloured vote is not a solid ethnic bloc, that appeals by parties will yield coloured votes and that we will see a more class-based, racialised politics emerging in rural and urban areas as other parties take their lead from the ANC's success. The 2000 local government success for the DA's explicit ethnic politics is a sign of things to come. Crucial to the ANC's 1999 success was its recognition that the electoral diversity of the populace and its use of this knowledge in its election campaigning.

Finally, the ANC's ability to maintain and increase the momentum it experienced in the Western Cape will perhaps set the precedent for a new kind of politics in that region. All the main political actors in the province now articulate coloured identity openly. It would be difficult to reverse this kind of politics in future. The 1999 election campaign and the results mean that the parties will increasingly develop 'coloured'-specific programmes and organisational strategies to draw out this vote in the Western Cape.

News of the death of 'coloured politics' is indeed greatly exaggerated. 